\title{
肥満患者と $\mathrm{CABG}$ 後低酸素血症に関する検討
}

$\begin{array}{lllllllll}\text { 河 内 和 宏 山 崎 和 裕 石 井 } & \text { 修 } \\ \text { 小 宮 達 彦 } & \text { 中 村 智 宏 神 崎 義 雄 }\end{array}$

\begin{abstract}
体外循環手術後の低酸素血症を予測する因子について検討した．術後人工呼吸器から離脱可能であつ た CABG 単独症例 53 例を対象とした．実測 $70 \%$ 以上の高濃度酸素吸入を必要とした症例群（H 群） 29 例と 70\%以下の酸素吸入を行った群（L 群） 24 例について周術期おける各種因子との関係につい て検討した（H 群 vs L 群)。術前因子では body mass index $(25.6 \pm 3.5 \mathrm{vs.} 23.3 \pm 2.8, p=0.012 ）$ が H 群において有意に高值であった. Respiratory index は両群ともに体外循環前後で低下するが H 群においてはとくに抜管後より低下遷延していた，H 群中 3 例は再挿管を要し全例晚期死亡した.

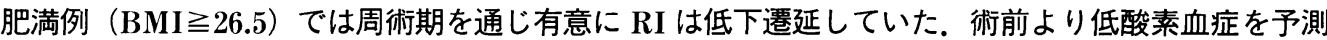
する因子は乏しいが肥満症例に対しては厳重な呼吸管理が要求されると思われた。日心外会誌 26 巻 2 号 : 83-86 (1997)
\end{abstract}

Keywords：体外循環手術, 術後低酸素血症

\begin{abstract}
Postoperative Hypoxia in Obese Patients following Coronary Artery Bypass Grafting
Kazuhiro Kochi, Kazuhiro Yamazaki, Osamu Ishii, Tatsuhiko Komiya, Tomohiro Nakamura and Yoshio Kanzaki (The Heart Institute, Department of Cardiovascular Surgery, Kurashiki Central Hospital, Kurashiki, Japan)

Postoperative hypoxia in 53 consecutively treat patients who underwent coronary artery bypass grafting $(\mathrm{CABG})$ and who were weaned from mechanical ventilation were studied. The 29 patients who required high concentration oxygen (more than 70\% H-group) were compared with the 24 patients who required lower concentration oxygen (less than $70 \% \mathrm{~L}$-group). The preoperative body mass index (BMI) was significantly higher in the H-group (25.6 \pm 3.5 ) than the L-group $(23.3 \pm 2.8) . \quad(p=0.012)$. Respiratory index (RI) decreased after extracorporeal circulation in all patients. The RI of the H-group during a stay in intensive care unit was significantly lower than that in the L-group. The RI in obese patients (BMI $\geqq 26.5$ ) showed a significant reduction. Late deaths were seen in 3 obese patients in the H-group. These data suggested that careful postoperative respiratory managements is necessary in obese patients. Jpn. J. Cardiovasc. Surg. 26 : 83-86 (1997)
\end{abstract}

体外循環にて酸素化能が低下することは明白で あるがその程度は個体により異なる11. ARDSの ような致命的な低酸素血症に陥る症例はごくまれ であるが，人工呼吸器からは離脱したものの高濃 度の酸素供給が必要となる程度の低酸素血症例は 臨床的に多々存在する。これらの症例は重篤な合 併症発生時には再挿管が必至となり長期呼吸管理 という，多臓器不全死の最大リスクファクターを 背負うこととなる ${ }^{2,3)}$. 体外循環術後の低酸素血

1996 年 3 月 21 日受付， 1996 年 9 月 4 日採用

倉敷中央病院心臓病センター心藏血管外科 $\bar{\top} 710$ 倉敷市美和 1-1-1

本論文の要旨は, 第 48 回日本胸部外科学会総会（1995 年 10

月，東京）に执いて発表した。
を予測する因子について，CABG 単独症例を対 象に検討した。

\section{対象と方法}

1993 年 1 月より 1994 年 12 月までに当院で施 行した冠動脈バイパス術単独症例のうち術前心機 能良好（LVEF 50\%以上）かつ術後人工呼吸器 から離脱可能であった 53 例を対象とした。人工 呼吸管理終了後 $\mathrm{PaO}_{2}$ を $70 \mathrm{mmHg}$ 以上とするた めに実測 70\%以上の高濃度酸素吸入（Intertech$002305 \mathrm{E}$ を用い $15 \mathrm{l} / \mathrm{min}$ ，ダイヤル $100 \%$ と設定 しうる酸素濃度の最大条件）を必要とした症例群 (H 群) 29 例と $70 \%$ 以下の酸素吸入を行った群 
（L 群）24 例について周術期における各種因子と の関係について検討した。

術前因子：呼吸機能（\%VC，一秒率），年齢， 喫煙歴（術直前までの喫煙者症例数）および肥満 度。

肥満度は body mass index（以下，BMI と略 す）を採用し，体重 $[\mathrm{kg}] /$ 身長 ${ }^{2}\left[\mathrm{~m}^{2}\right]$ とし，日本 肥満学会の定義にて 26.5 以上を肥満と定義した.

術中因子：体外循環時間，大動脈遮断時間，お よび手術時間. 開胸操作の有無.

術後因子：術後血行動態（LOS の指標として 術後使用最高力エコラミン $10 \gamma$ 以上の症例数), 腎機能障害症例数 (術後 $\mathrm{Cr} 2.0$ 以上の症例数), 水分出納（術 2 日間の水分バランスの平均を体表 面積で除したもの)，人工呼吸管理時間おょび集 中治療室滞在日数.

周術期酸素化能: 指標として respiratory index（以下，RI と略す）を用いた。 RI は簡便 式を採用し $\mathrm{PaO}_{2}[\mathrm{mmHg}] /$ 供給酸素濃度 $[\%]$ と した。

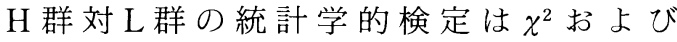
student's $t$ 検定を用い， $p$-value 0.05 以下をも って有意差ありとした。

表 1 術前因子と術後酸素化能

\begin{tabular}{lrrl}
\hline & $\mathrm{H}$ 群 $(n=29)$ & $\mathrm{L}$ 群 $(n=24)$ & \multicolumn{1}{c}{ 有意差 } \\
\hline 年齢(歳) & $64.9 \pm 7.3$ & $62.5 \pm 7.8$ & なし \\
体重 $(\mathrm{kg})$ & $63.2 \pm 11.5$ & $58.9 \pm 7.6$ & $(p=0.048)$ \\
身長 $(\mathrm{cm})$ & $159.9 \pm 8.9$ & $159.9 \pm 8.7$ & なし \\
$\mathrm{BMI}$ & $25.6 \pm 3.5$ & $23.3 \pm 2.8$ & $(p=0.012)$ \\
喫煙歴(例 $)$ & 16 & 15 & なし \\
肺活量 $(\%)$ & $111.8 \pm 12.7$ & $108.4 \pm 16.6$ & なし \\
1 秒率 $(\%)$ & $70.2 \pm 7.1$ & $71.7 \pm 6.3$ & なし \\
\hline
\end{tabular}

結

果

術前因子：術前 $\% \mathrm{VC}$ と 1 秒率，年齢，喫煙症 例数で有意差を認めなかった。肥満度は（25.6土 3.5 vs. $23.3 \pm 2.8, p=0.012 ）$ と H 群において有 意に高值であった（表 1 ).

術中因子：体外循環時間，大動脈遮断時間，手 術時間で有意差を認めなかった（表 2).

術後因子：術後 LOS, 腎機能障害症例数, お よび人工呼吸管理時間において有意差を認めなか った（表 3). 体外循環前の RI は $(4.4 \pm 1.1$ vs. $4.8 \pm 0.80, p=0.06 ）$ と両群ともに低值の傾向にあ り，体外循環後の RI は $(2.4 \pm 1.0$ vs. $2.9 \pm 0.9$, $p=0.05 ）$ と有意に H 群にて低值であった。抜管 前, 抜管後, おょび ICU 退室時の RI はそれぞ れ (2.1 \pm 0.6 vs. $2.5 \pm 0.9, p=0.09),(1.4 \pm 0.7$ vs. $2.5 \pm 0.8, p=0.0001)$ ，および $(1.9 \pm 1.2$ vs. $2.6 \pm$ $0.6, p=0.02 ） て ゙ あ り$ 全症例において体外循環後 の酸素化能の回復遅延を認めたが，有意に $\mathrm{H}$ 群 において遷延していた（図 1).

術後酸素化能改善と予後：H群での抜管後の

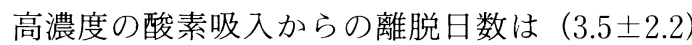
であり, ICU 滞在日数は $(6.8 \pm 4.1$ vs. $3.9 \pm 1.2$, $p=0.001 ）$ と有意に延長していた（ $p=0.001 ）$. 抜管 1 週間以内の再挿管は 3 例で（喘息発作 2 例, 誤飲 1 例）全例 $\mathrm{H}$ 群で晚期死亡例であった

表 2 術中因子と術後酸素化能

$\mathrm{H}$ 群 $(n=29) \mathrm{L}$ 群 $(n=24)$ 有意差

体外循環時間(分) $190.3 \pm 67.2173 .2 \pm 56.3$ なし 大動脈遮断時間 (分) $92.6 \pm 33.7 \quad 95.5 \pm 33.0$ なし 手術時間(時間) $8.3 \pm 2.5 \quad 7.5 \pm 2.2$ なし 開胸症例数 (例)
10 なし

表 3 術後因子と術後酸素化能

\begin{tabular}{lccl}
\hline & $\mathrm{H}$ 群 $(n=29)$ & $\mathrm{L}$ 群 $(n=24)$ & \multicolumn{1}{c}{ 有意差 } \\
\hline LOS 症例数 (例) & 5 & 4 & なし \\
腎障害症例数 (例) & 6 & 5 & なし \\
水分出納 $\left(\mathrm{ml} / \mathrm{m}^{2}\right)$ & $-168 \pm 648$ & $-503 \pm 697$ & なし \\
人工呼吸管理時間(時間) & $30.6 \pm 24.2$ & $21.9 \pm 14.2$ & なし \\
集中治療室滞在日数 & $6.8 \pm 4.1$ & $3.9 \pm 1.3$ & $p=0.0013$ \\
\hline
\end{tabular}




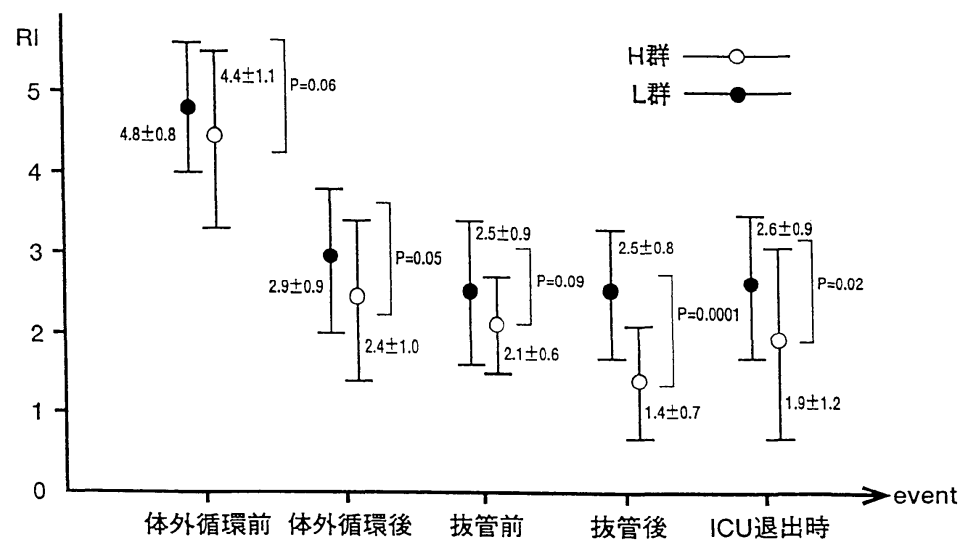

図 1 周術期 RI 推移

全症例において体外循環後の酸素化能は低下する傾向を認めた。とくに有意に $\mathrm{H}$ 群において遷延していた，RI：respiratory index, H：70\%酸素吸入群，L： $70 \%$ 以下の酸素吸入群.

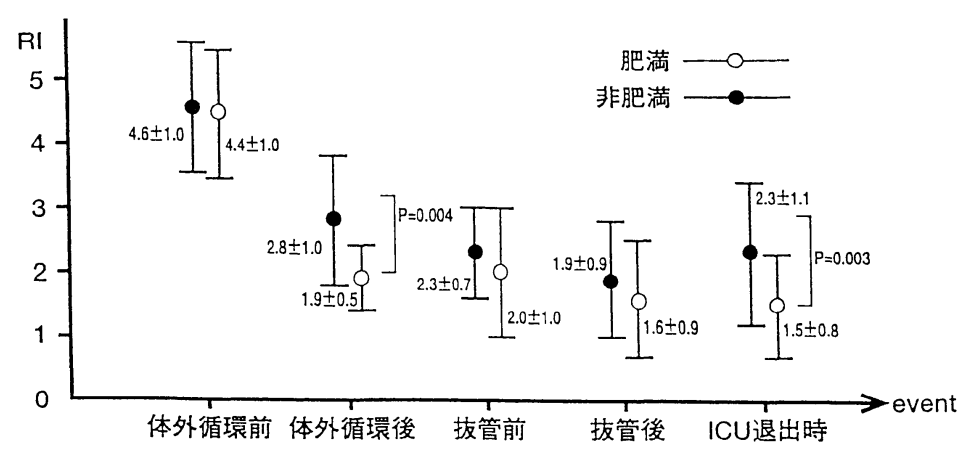

図 2 肥満例の RI 推移

肥満例において体外循環後の酸素化能は低下遷延する傾向を認めた，RI：respiratory index.

(肺炎 2 例, 前縦隔炎 1 例).

肥満例と非肥満例との検討：肥満例は 10 例 (19\%) であり，H群 8 例，L群 2 例であった。 体外循環前の RI は $(4.4 \pm 1.0$ vs. $4.6 \pm 1.0)$ 同等 であったが，体外循環後の RI は（1.9 00.5 vs. $2.8 \pm 1.0, p=0.004)$ と有意に肥満例にて低值であ った，抜管前，抜管後，および ICU 退室時の RI

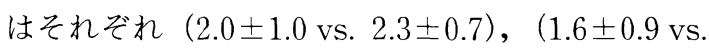
$1.9 \pm 0.9)$ ，および $(1.5 \pm 0.8$ vs. $2.3 \pm 1.1, p=0.003)$ であり全症例において体外循環後の酸素化能の回 復遅延を認めたが，有意に肥満例において遷延し ていた（図 2).

\section{考察}

体外循環手術後の最大のイベントは，麻酔から の完全覚醒と手術に起因する中枢神経系合併症の ないことを前提とした人工呼吸器からの離脱 (“抜管”) である。離脱条件としては良好な換気 能と酸素化能が要求される。藏外科領域では主 として正中切開を多用することから手術操作その もので肺の虚脱をもたらす要因は少ない.内胸動 脈剥離は開胸操作を合併しやすいが諸家の報告の ごとく, 術後呼吸器系トラブルの危険因子ではな ( ${ }^{4,5)}$. 麻酔からの覚醒遅延, COPD, および中枢 
神経障害が関与しない限り呼吸パターンは障害さ れず換気障害が起こることは少ないと考えられ る.ゆえに抜管抢よびその後の呼吸管理上の最大 の焦点は酸素化能ということになる．低酸素血症 にて人工呼吸器から離脱困難な症例は術後合併症 に対し無防備となる2,6,7).

体外循環手術後の酸素化能を予測する術前因子 としてわれわれの検討では肥満度のみがあげられ た。肥満者では横隔膜や肋間筋の脂肪沈着による 機能的残気量低下と肺そのもののコンプライアン スの低下が知られている。肥満患者の術後低酸素 血症はこれら生理的拘束性変化とさらに仰臥位に おける腹部臓器による横隔膜圧排と上気道閉塞に よる無呼吸が原因となる ${ }^{8,9}$. ただし呼吸機能の 基本的パラメーターである一秒量や肺活量につい ては超肥満者でない限り異常を指摘できないとさ れ，拘束性障害の数量的評価を術前に下すことは 困難である。自験例でも肥満者と非肥満者での\%

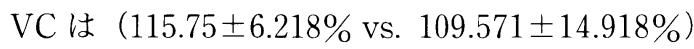
と有意な差を認めず拘束性障害を見いだすことは できなかったが, 術後低酸素血症が重症化かつ遷 延する結果を得た。低酸素血症からの回復には諸 家の報告からも打招む称数週間を要するとされ る。以上より抜管に際しては適切な酸素化能が人 工呼吸管理時に観察される必要があり，われわれ はRI が 2 以上の症例は躊躇なく抜管可能, 1.5〜2 の症例は理学療法を積極的に施行しつつ 可能な限り RI を高めて抜管するようにしてい る.とくに肥満症例では座位での管理が酸素化能 を高めると考え理学療法に取り入れている.

\section{結 論}

術前より低酸素血症を予測する因子は乏しいが 肥満症例に対しては抜管後も低酸素血症が遷延す る危険性が高く厳重な呼吸管理が要求されると思 われた。

\section{文献}

1) Johnson, D., Thomson, D., Hurst, T. et. at.: Neutrophil-mediated acute lung injury after extracorporeal perfusion. J. Thorac. Cardiovasc. Surg. 107 : 1193-1201, 1994.

2) Locicero, J, 11l., Mccann, B., Massad, M. et al. : Prolonged ventilatory support after open-heart surgery. Critical Care Medicine 20: 990-902, 1992.

3) Kollef, H. M., Wragge, T. and Pasque, C.: Determinants of mortality and multiorgan dysfunction in cardiac surgery patients requir ing prolonged mechanical ventilation. Chest 107 : 1395-1401, 1995.

4) Hurlbut, D., Myers, M. L. and Lefcoe, M. : Pleuropulmonary morbidity: internal thoracic artery versus saphenous vein graft. Ann. Thorac. Surg. 50 : 959-964, 1990.

5）富田伸司, 坂田隆造, 梅林雄介ほか：冠血行再建 術後の呼吸機能の検討一開胸操作に関連して一. 胸部外科 47: 528-531, 1994.

6) Listello, D. and Sessler, N.C.: Unplanned extubation. Chest 105: 1496-1503, 1994.

7) Shapira, N, Zabatino, S. M., Ahmed, S. et. at. Determinants of pulmonary function in patients undergoing coronary bypass operations. Ann. Thorac. Surg. 50 : 268-273, 1990.

8）田口 治：肥満者にみられる各種病態と合併症 一呼吸機能障害. 日本臨床 53: 343-348, 1995.

9) Luce, J. M. : Respiratory complication of obesity. Chest 78: 626-631, 1980. 